\title{
Mapping bird assemblages in a Mediterranean urban park: Evidence for a shift in dominance towards medium-large body sized species after 26 years
}

\author{
Corrado Battisti ${ }^{1, *} \&$ Giuseppe Dodaro ${ }^{2}$
}

\begin{abstract}
1 “Torre Flavia” LTER (Long Term Ecological Research) Station, Città Metropolitana di Roma Capitale, Servizio “Aree protette - parchi regionali”, via Tiburtina, 691, 00159 Rome, Italy and, University of Rome III, Department of Science, viale Marconi, 446, 00146 Rome, Italy; e-mail: c.battisti@cittametropolitanaroma.gov.it

2 Sustainable Development Foundation, via Garigliano 61/a, 00198 Rome, Italy; e-mail: dodaro@susdef.it

* Corresponding author: c.battisti@cittametropolitanaroma.gov.it
\end{abstract}

\begin{abstract}
We assessed the structure of the breeding bird assemblage in a Mediterranean urban park in 2012, and compared it with data gathered in the same area in 1986. Since 1986, Wryneck (Jynx torquilla) territories have disappeared from the study area, while breeding pairs of Green Woodpecker (Picus viridis) and the introduced Rose-ringed Parakeet (Psittacula krameri) have colonized the park. We observed a significant decrease in density of the Italian Sparrow (Passer italiae) and a significant increase in Starling (Sturnus vulgaris). At the assemblage level, overall bird densities decreased but total bird biomass increased due to the increase in density of (often cavity-nesting) medium to large body sized species (such as woodpeckers, Rose-ringed Parakeet and Starling). A presumed increase in mature tree availability and in predation by synanthropic species (e.g. crows) may explain the high density and biomass of primary and secondary cavity nesters characterized by medium-to-large body sizes. The decline of Sparrows and Wryneck may reflect the decreasing trend at the continental scale.
\end{abstract}

KEY WORDS: mapping method, long time span, Jynx torquilla, Psittacula krameri, Sturnus vulgaris, Passer italiae

\section{INTRODUCTION}

Urban parks have been considered important green areas that, embedded in anthropized landscapes, host specific bird assemblages (BEISSINGER \& OSBORNE, 1982; FERNÁNDEZJURICIC \& JOKIMÄKI, 2001; KELCEY \& RHEINWALD, 2005; CHACE \& WALSH, 2006; Clergeau et al., 2006; Ortega-Álvarez \& MACGREGOR-FORS, 2009; RAMALHO \& HoBBS, 2012). In this sense, several studies have evidenced their peculiar composition and structure (for central and northern Europe: DE GRAAF et al., 1991; JOKIMÄKI \& SUHONEN, 1993; for Mediterranean: FERNÁNDEZ-JURICIC, 2000; SORACE \& GUSTIN, 2008; FRAISSINET \& FULGIONE, 2008; see also for review: MCKINNEY, 2002; ClergeAu et al., 2006). In particular, in the last decades several generalist synanthropic species, both native and non-native, have increased in density in urban areas, changing the total richness and inducing evident turnovers in species assemblages (SORACE \& GUSTIN, 2008). Among them, species such as parakeets, starlings and crows may be considered as urban exploiter species, while many specialized species have shown a progressive decline (PALOMINO \& CARRASCAL, 2006). Although these changes are documented in literature (KELCEY \& RHEINWALD, 2005; MCCAFFREY \& MANNAN, 2012), empirical research comparing bird assemblages over large time spans is scarce, at least for Mediterranean urban parks.

In 1986, breeding birds were censused in a large urban park of central Italy (Rome) using a mapping method (BATTISTI, 1986). After 26 years (2012) we carried out a comparable study 
in the same site, using the same protocol by the same researcher (CB). This comparison allowed us to detect changes in density at species level, and in structure at assemblage level over this long time span (1986-2012). Data were analyzed using a bi-variate metric of diversity (Abundance/ Biomass curves) based on a comparison of cumulative species abundance and biomasses, used to detect structural changes at community level (WARWICK \& ClARKE, 1994; MAGURRAN, 2004).

\section{MATERIAL AND METHODS}

The area studied was inside the Villa Doria Pamphili (Rome, central Italy), a large historical urban park (120 hectares, $50 \mathrm{~m}$ a.s.l.; Site of Conservation Interest 'Habitat' Directive 92/43/

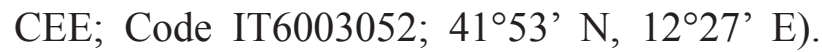
Inside the park, we identified a study area (17.96 ha wide) characterized by native (Quercus ilex, Q. pubescens, Q. petrae and, secondarily, Ulmus campetris, Laurus nobilis, Cercis siliquastrum) and ornamental trees (Pinus pinea, Cedrus libanotica, Aesculus hippocastanum, Robinia pseudoacacia, Cupressus sp., Ailanthus altissima) surrounded by mowed grasslands (mainly Graminaeae, Malvaceae, Compositae; Celesti-Grapow, 1995).

Breeding bird assemblages were monitored by means of a mapping census method (BIBBY et al., 2000; SuTHERLAND 2006). During the 2012 breeding seasons (March-June), a number of periodic visits $(n=12)$ were carried out with a sampling effort ( 25 hours of field sampling) comparable to the research effort carried out in 1986 (12 visits; 25 hours). During each visit, the observer collected data following a non-linear transect (about 2,500 m-long; speed: $1.5 \mathrm{~km} /$ hour) in the early morning (07.00 -10.00 a.m.) covering all the study area. Contacts (i.e. records of each individual breeding bird) were noted on a local map (scale 1:2,000, Technical Regional Map; RegiOne LAZIO, 1990). The primary and secondary tree vegetation was the same as in 1986, and no evident changes in their relative abundance had occurred when compared to 2012. No form of wood coppicing or clearing had been carried out in the period between the two surveys (CELESTI GRAPOW, 1995; CARBONE \& FRASSINETI, 2001; RICOTTA et al., 2001).

Species-specific maps were created and species-specific territories were obtained following the clustering procedure described in BIBBY et al. (2000). We considered a "territory" as a range area where a territorial species pair was considered to breed (BIBBY et al., 2000). Due to the limited vocalizations or territoriality of some species (e.g. sparrows Passer sp., Hooded Crow Corvus cornix, Rose-ringed Parakeet Psittacula krameri) an estimated value of density of such species was drawn from the counting of the individuals and checking for their nests. Species with crepuscular or nocturnal activity (e.g. Strigiformes and Caprimulgiformes) and individuals flying very high $(>25 \mathrm{~m})$ were not considered. For nomenclature we refer to Italian Sparrow Passer italiae since HERMANSEN et al. (2011) established definitively that this species is a stabilized hybrid.

We analysed data at assemblage and species levels for both time periods. We refer to the term "assemblage" to indicate a set of taxonomically related species that co-occur at a given time and spatial scale in a site (VERNER, 1984; FAUTH et al., 1996). The following parameters were calculated: (i) species richness, as the number of species occurring in the study area for the overall assemblage (STot); (ii) total number of breeding pairs (Ntot) and breeding pair density (D), this last expressed as number of territories (i.e. breeding pairs) $/ 10$ ha and calculated for each species and all species (DTot); (iii) relative frequency for each species both in abundance $\left(\mathrm{f}_{\mathrm{A}}\right.$ as the ratio: $\mathrm{D} / \mathrm{DTot}$; species with $\mathrm{f}_{\mathrm{A}}>0.05$ were considered dominant species; TURČEK, 1956) and biomass ( $f_{B}$ as the ratio: species-specific body weight/total biomass); (iv) Shannon diversity index (H'; SHANNON \& WEAVER, 1963, as $\mathrm{H}=-\Sigma \mathrm{f}_{\mathrm{A}} \ln \mathrm{f}_{\mathrm{A}}$ ); (v) total biomass (TB; both at species and assemblage level), corresponding to the sum of body weight of all censused 
individuals, expressed in g). To calculate the biomass values, mean body mass values were obtained from CRAMP \& SIMMONS (1977, 1980, 1983), CRAMP (1988) and CRAMP \& PERRINS (1993). For each species in the assemblage, we additionally obtained their cumulative frequency for abundance and for biomass. We then ranked the cumulative frequencies from the most to the least important along the $\mathrm{x}$-axis in a Cartesian space in order to obtain two curves, for cumulative abundance and for biomass (ABC curves; WARWICK, 1986; MAGURRAN, 2004). In particular, species abundance curves indicate the relative distribution of the spatial niche of the species (using abundance as a proxy), while biomass curves indicate the relative distribution of the energy flow in the assemblage, according to the trophic resources used by species (MAgurRan, 2004). The ABC approach has been applied in several animal assemblages (PENCZAK \& KRUK, 1999; MAgurRAN \& PHILLIP, 2001; PRETE et al., 2012), but rarely in birds (e.g., BENASSI et al., 2009).

The comparison between relative frequencies in abundance of each species in paired years (1986 vs 2012; only for species with at least a census of $>5$ total pairs) was tested using $\chi^{2}$ test. We performed the Kolmogorov-Smirnov test (two-tailed) to compare the diversity indices and the frequency distribution between curves (1986 vs 2012). We used statistical package Primer version $4.02 \mathrm{i}$ for Windows and SPSS 13.0 for Windows (SPSS Inc. 2003). Significance levels were set at $p<0.05$. We checked for data reliability (controlling for standardization, replication, data-independence) following BATTISTI et al. (2014).

\section{RESULTS}

In the 2012 breeding season, we sampled 20 breeding species (compared to 23 in 1986; Table 1). Comparing data between years, in 2012 we no longer observed Wryneck Jynx torquilla, which had been present in 1986, and we recorded pairs of Green Woodpecker Picus viridis and
Rose-ringed Parakeet for the first time in 2012. We observed a significant decrease in frequency of abundance $(\mathrm{P}<0.05)$ for Italian Sparrow and Wryneck and an increase for Starling Sturnus vulgaris $(\mathrm{P}<0.05)$ and Rose-ringed Parakeet $\left(\mathrm{P}<0.01 ; \chi^{2}\right.$ test; Table 1$)$. At assemblage level, we also observed contrasting trends among parameters: from 1986 to 2012, the total density decreased and the total biomass increased (Table 1). In $2012,36.8 \%$ of total biomass was related to only two cavity nester species (Starling and Rose-ringed Parakeet). Cavity nesters markedly increased their total frequency in biomass (1986: $0.353 ; 2012$ : 0.549).

Diversity index H' showed a weak, not significant change between 1986 and 2012 $\left(\mathrm{H}^{\prime}=2.73\right.$ vs $\mathrm{H}^{\prime}=2.69 ; \mathrm{Z}=0.384, \mathrm{P}=0.998$; Kolmogorov-Smirnov test). The ABC curves show that (i) biomass curves are higher when compared to abundance curves in both years; (ii) curves for 2012 (abundance and biomass) cumulate early when compared to curves for 1986. Differences between biomass cumulative curves are significant $(Z=1.991, P=0.003$; Kolmogorov-Smirnov test; Fig. 1).

\section{DISCUSSION}

Our data show that over a 26-year period, quantitative changes in breeding bird assemblages occurred in our study area, but these differences were mainly driven by the population trends of a limited set of species. Some species, occurring in 1986, showed a significant decline in their frequency (such as sparrows) or were not recorded at all in 2012 (Wryneck). Other species newly appeared (Rose-ringed Parakeet, Green Woodpecker) or significantly increased both in density and in their frequency (Starling). Roseringed Parakeet, absent in 1986 but dominant in 2012, was introduced into European urban areas in the 1980s (CZAIJKA et al., 2011) and shows a recent and strong expansion in Italy (MORI et al., 2013). This parakeet is considered a new invasive alien species occurring in urban European ecosystems where it can compete 
TABLE 1

Breeding bird species of the Villa Doria Pamphili urban park (Rome, central Italy) for 1986 (data from Battisti 1986) and 2012 (original data). $\mathrm{C}=$ cavity nester species. Ntot $=$ total number of breeding pairs, $\mathrm{D}=$ species density (pairs/10 ha), $\mathrm{f}_{A}=$ relative frequency in abundance (in bold, the dominant species: $\mathrm{f}>0.05$ ), $\mathrm{f}_{\mathrm{B}}=$ relative frequency in biomass; TB $=$ total biomass (in g). Values of $\chi^{2}$ (comparison between frequency in abundance) were reported only for species with at least $>5$ total pairs censused; $*=\mathrm{P}<0.05 ; * *=\mathrm{P}<0.01$ ).

\begin{tabular}{|c|c|c|c|c|c|c|c|c|c|c|c|}
\hline \multirow[b]{2}{*}{ Species } & \multirow[b]{2}{*}{ Ntot } & \multicolumn{4}{|c|}{1986} & \multicolumn{5}{|c|}{2012} & \multirow[b]{2}{*}{$\chi^{2}$ test } \\
\hline & & $\mathrm{D}$ & $\mathrm{f}_{\mathrm{A}}$ & TB & $\mathrm{f}_{\mathrm{B}}$ & Ntot & $\mathrm{D}$ & $\mathrm{f}_{\mathrm{A}}$ & ТВ & $\mathrm{f}_{\mathrm{B}}$ & \\
\hline Sylvia atricapilla & 38.5 & 21.4 & 0.177 & 643.2 & 0.087 & 28 & 15.6 & 0.166 & 468.6 & 0.057 & 0.125 \\
\hline Troglodytes troglodytes & 30.5 & 17 & 0.14 & 271.7 & 0.037 & 19.5 & 10.9 & 0.116 & 173.5 & 0.021 & 0.297 \\
\hline Passer italiae (C) & 15.5 & 11.1 & 0.092 & 668.4 & 0.091 & 3 & 1.7 & 0.018 & 100.6 & 0.012 & $4.917 *$ \\
\hline Serinus serinus & 15.5 & 8.6 & 0.071 & 155.3 & 0.021 & 4 & 2.2 & 0.023 & 40.2 & 0.005 & 3.657 \\
\hline Turdus merula & 15 & 8.3 & 0.069 & 1219.1 & 0.166 & 10 & 5.6 & 0.06 & 817.8 & 0.099 & 0.047 \\
\hline Parus major (C) & 14 & 7.8 & 0.064 & 280.4 & 0.038 & 13 & 7.2 & 0.077 & 260.2 & 0.032 & 0.047 \\
\hline Fringilla coelebs & 12.5 & 7 & 0.057 & 292.3 & 0.04 & 7.5 & 4.2 & 0.045 & 174.4 & 0.021 & 0.114 \\
\hline Sturnus vulgaris $(\mathrm{C})$ & 10 & 5.6 & 0.046 & 946.9 & 0.129 & 20 & 11.1 & 0.118 & 1883 & 0.228 & $4.711^{*}$ \\
\hline Cyanistes caeruleus (C) & 9.5 & 5.3 & 0.044 & 105.8 & 0.014 & 15 & 8.4 & 0.089 & 166.7 & 0.02 & 1.728 \\
\hline Jynx torquilla $(\mathrm{C})$ & 8.5 & 4.7 & 0.039 & 312.2 & 0.042 & & & & & & $5.354^{*}$ \\
\hline Erithacus rubecula & 6.5 & 3.6 & 0.03 & 115.8 & 0.016 & 8 & 4.5 & 0.048 & 143.3 & 0.017 & 0.177 \\
\hline Certhia brachydactyla (C) & 5 & 2.8 & 0.023 & 44.5 & 0.006 & 5.5 & 3.1 & 0.033 & 48.7 & 0.006 & 0.131 \\
\hline Regulus ignicapilla & 5 & 2.8 & 0.023 & 27.8 & 0.004 & 7 & 3.9 & 0.041 & 38.7 & 0.005 & 0.441 \\
\hline Passer montanus (C) & 5 & 2.8 & 0.023 & 127.9 & 0.017 & & & & & & 2.349 \\
\hline Carduelis chloris & 4.5 & 2.5 & 0.021 & 120.5 & 0.016 & 3.5 & 1.9 & 0.02 & 93.9 & 0.011 & \\
\hline Luscinia megarhynchos & 2 & 1.7 & 0.014 & 66.8 & 0.009 & 1 & 0.6 & 0.007 & 21.9 & 0.003 & \\
\hline Cettia cetti & 3 & 1.7 & 0.014 & 46.8 & 0.006 & & & & & & \\
\hline Corvus cornix & 3 & 1.7 & 0.014 & 1686.7 & 0.229 & 3 & 1.7 & 0.018 & 1657.3 & 0.201 & \\
\hline Carduelis carduelis & 2 & 1.1 & 0.009 & 35.5 & 0.005 & 4 & 2.2 & 0.023 & 71.9 & 0.009 & \\
\hline Sylvia melanocephala & 2 & 1.1 & 0.009 & 26.6 & 0.004 & & & & & & \\
\hline Muscicapa striata & 2 & 1.1 & 0.009 & 32.2 & 0.004 & & & & & & \\
\hline Dendrocopos major (C) & 1.5 & 0.8 & 0.007 & 117.6 & 0.016 & 3 & 1.7 & 0.018 & 245.5 & 0.03 & \\
\hline Aegithalos caudatus & 1 & 0.6 & 0.005 & 7.8 & 0.001 & 2 & 1.1 & 0.012 & 14.5 & 0.002 & \\
\hline Picus viridis $(\mathrm{C})$ & & & & & & 3 & 1.7 & 0.019 & 668.2 & 0.081 & \\
\hline Psittacula krameri $(\mathrm{C})$ & & & & & & 9 & 5 & 0.053 & 1152.6 & 0.14 & $8.844^{* *}$ \\
\hline Total & 212 & 121.1 & 1 & 7351.8 & & 169 & 94.1 & 1 & 8241.4 & & \\
\hline
\end{tabular}

with many primary and secondary hole-nesting species (DODARO \& BATTISTI, 2014). The Green Woodpecker has shown a moderate increase at the continental scale in recent years (GREGORY et al., 2007), and the appearance of the species in our study area corroborates such a continent-wide increase. Starlings are among the most common secondary cavity-nesters in Europe (FEARE, 1984; KoENIG, 2003), breeding in central Italy from the 1970s and nowadays occurring almost everywhere as a breeder (CECERE et al., 2005). Interestingly, while starlings are known to compete for nesting cavities with Rose-ringed Parakeets (DODARO \& BATTISTI, 2014, see also STRUBBE \& MATTHYSEN, 2007; 2009a; 2009b; CZAIJKA et al., 2011; NEWSON et al., 2013), both species have become more common in our study area, probably because tree maturation may have increased the availability of suitable nesting cavities. Similarly to the European Sparrow, the 
Italian Sparrow significantly declined from 1986 to 2012, supporting the evidence of its general decline in the last decade (SUMMER-SMITH, 2003; BRICHETTI et al., 2008; CAMPEDELLI et al., 2012).

Different factors and processes at different scales may act to determine the observed patterns, as stated for urban parks in nonMediterranean contexts (e.g. JOKIMÄKI, 1999). At the local scale, the availability of large native and ornamental trees (and their maturation over the last 26 years), combined with the ability of Rose-ringed Parakeets to enlarge cavities for nesting (ORCHAN et al., 2013), may explain the occurrence and high density of several mediumlarge cavity nesters (ANGELSTAM \& MIKUSIŃKI, 1994; MIKUSIŇSKI et al., 2001; PASINELLI, 2007; STRUBBE \& MATTHYSEN, 2007; ZANGARI et al., 2013), while the decline of sparrows and Wryneck follows a larger scale (continental) process (GREGORY et al., 2007; REIF, 2013).
Although the number of species slightly decreased from 1986 to 2012, the biomass at assemblage level increased because of an increase in the density of medium-large bodied species (such as woodpeckers, Rose-ringed parakeet, Starling). The ABC curves (Fig. 1) emphasize the different ecological roles that the biomass and abundance parameters have at community level. When compared to 1986, assemblage energy flow has been progressively controlled by a set of medium-large bodied species. Interestingly, the two more common medium-large species (Rose-ringed Parakeet and Starling) are also cavity nesters, and total frequency in biomass of cavity nesters has markedly increased from 1986 to 2010. Presumably, in urban habitats, where egg and juvenile predation by crows and other synanthropic predators (rats, feral cats) can be very high, this ecological trait could be selectively favored (CROCI et al., 2008; JOKIMÄKI \& HuHTA, 2000; JOKIMÄKI et al., 2005; SERESS \& LIKER, 2015).

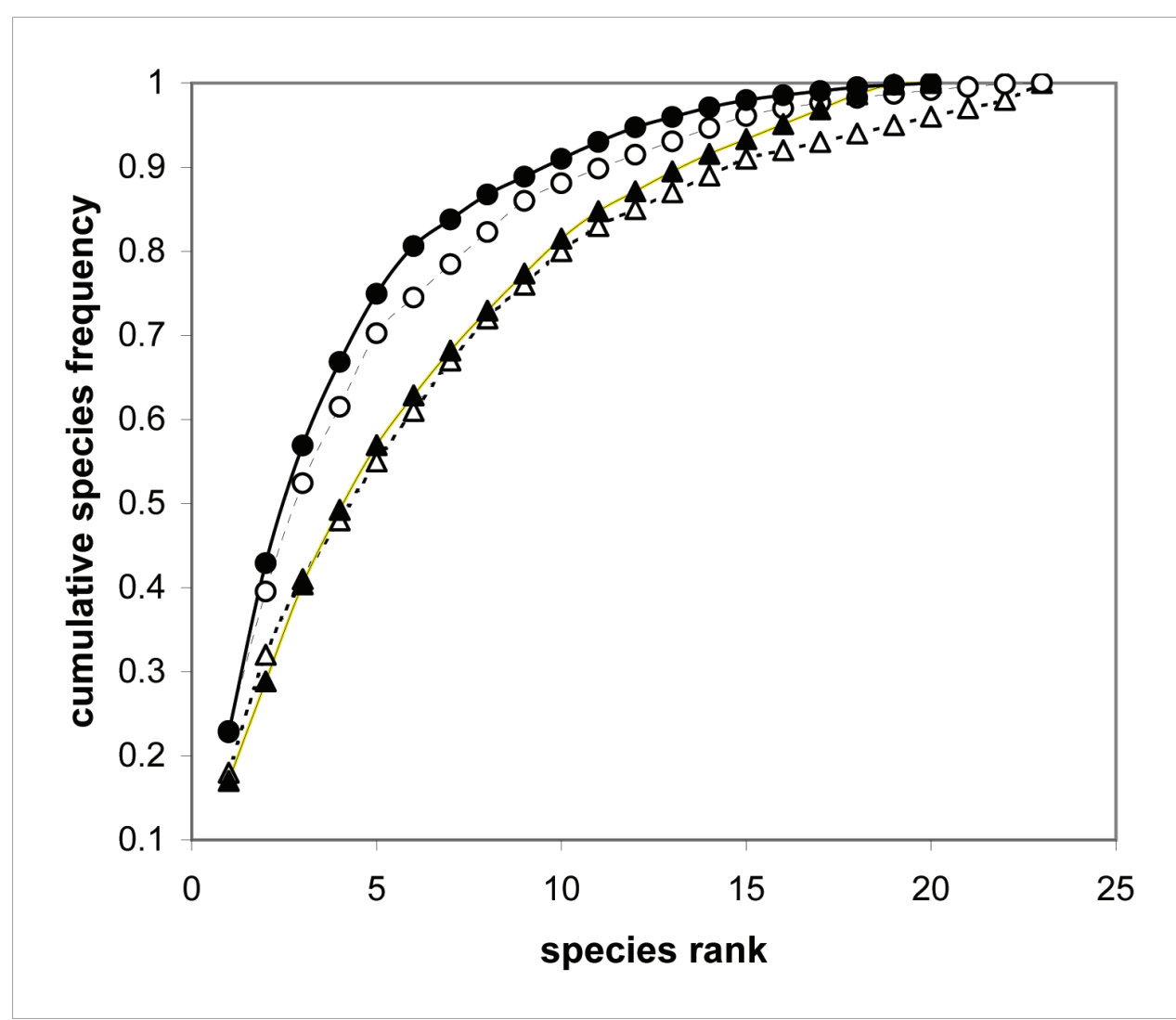

Fig. 1. - Abundance-Biomass Comparisons (ABC curves) for the breeding bird assemblages in Villa Pamphili urban park (central Italy). Circles: biomass cumulative frequency; triangles: abundance cumulative frequency (white and dashed lines: 1986; black and continuous lines: 2012). 
When abundance and biomass curves are compared, we then may obtain information on the structure of assemblages, i.e. if dominated by small bodied and highly abundant species or by large bodied and less abundant species. When biomass curves cumulate before the abundance curves, it is an indication that a higher number of relatively large bodied species occur in a more mature assemblage (MAGURRAN, 2004). In our case, in both years we observed biomass curves cumulating before the abundance curves. Nevertheless, this trend appears to be more prominent in 2012 when the biomass curve cumulated significantly earlier when compared to data sampled 26 years earlier. Early-cumulating biomass curves may indicate that more individuals with larger body size (and dominant in biomass) occur in the assemblage. Following this model, we observed that bird assemblages progressively changed toward species with larger body size and lesser abundance.

It should however be noted that our data may be affected by some weaknesses: i) it has been evidenced that the sampling performance of the same observers changes during large time spans (observer effect; see MAGURRAN et al., 2010); ii) our data belong to a single urban park and, therefore, may be affected by local environmental constraints and casual factors; iii) within our time span, we carried out the study in two years only. Nevertheless, our data have some points of strength: i) this is the first study carried out over a large time span in a Mediterranean urban park that highlights changes in assemblage structure with a shift toward medium-large bodied species; ii) we confirmed, at a local level, changes in density matching analogous trends at a larger scale: i.e. an increase for Rose-ringed Parakeet (see MORI et al., 2013; PYŠEK \& HulME, 2011) and a decrease for Italian Sparrow and Wryneck (see GREGORY et al., 2007); iii) for Starling, a species stable or moderately declining at continental scale (GREGORY et al., 2007; FREEMAN et al., 2007), we observed an increase in density matching the national trend (CAMPEDELLI et al., 2012); iv) finally, at assemblage level, we confirmed the general pattern described from
REIF (2013) at continental scale, i.e. smaller body sized species are declining while species with larger body sizes have increased or at least shown a less negative trend.

\section{ACKNOWLEDGMENTS}

Three anonymous reviewers, the Editor-inChief (Isa Schön) and the branch Diederik Strubbe have largely improved both the first and final drafts of the manuscript providing useful comments and suggestions. A. Zocchi reviewed the English language.

\section{REFERENCES}

ANGELSTAM P \& MiKUSIŃSKI G (1994). Woodpeckers assemblages in natural and managed boreal and hemiboreal forests - a review. Annales Zoologici Fennici, 31:157-172.

Battisti C (1986). Censimento degli uccelli nidificanti in un parco urbano (Villa Doria Pamphili, Roma). Avocetta, 10:37-40.

Battisti C, Dodaro G \& Franco D (2014). The data reliability in ecological research: a proposal for a quick self-assessment tool. Natural History Sciences, 1:75-79.

BEISSINGER SR \& OSBORNE DR (1982). Effects of urbanization on avian community organization. Condor, 84:75-83.

Benassi G, Battisti C \& Luiselli L (2009). Applying Abundance/Biomass comparisons in breeding bird assemblages of a set of remnant wetlands in Central Italy. Journal of Mediterranean Ecology, 10:13-18.

Bibby CJ, Burgess ND, Hill DA \& Mustoe SH (2000). Bird census techniques. II Ed. Academic Press, Londra, UK.

Brichetti P, Rubolini D, Galeotti P \& FAsola $M$ (2008). Recent declines in urban Italian Sparrow Passer (domesticus) italiae populations in Northern Italy. Ibis, 150:177-181.

Campedelli T, Buvoli L, Bonazzi P, Calabrese L, Calvi G, Celada C, Cutini S, De Carli E, Fornasari L, Fulco E, LA GioIA G, LONDI G, Rossi P, Silva L \& Tellini Florenzano G (2012). Andamenti di popolazione delle specie comuni nidificanti in Italia: 2010-2011. Avocetta, 36:121-143. 
CARBONE F \& FRASSINETI M (2001). I parchi naturali di Roma. Ente Roma Natura, Roma.

Cecere JC, Sorace A \& De Santis E (2005). Distribuzione dello Storno Sturnus vulgaris nella città di Roma. Alula, 12: 85-86.

Celesti Grapow L (1995). Atlante della flora di Roma: La distribuzione delle piante spontanee come indicatore ambientale. Comune di Roma, Argos edizioni, Roma.

CHACE JF \& WALSH JJ (2006). Urban effects on native avifauna: a review. Landscape and Urban Planning, 74: 46-69.

Clergeau P, Croci S, Jokimäki J, KaisanlahtiJOKIMÄKI M-L \& DINETTI M (2006). Avifauna homogenisation by urbanisation: analysis at different European latitude. Biological Conservation, 127: 336-344.

Cramp S \& PERrins CM (1993). The Birds of the Western Palearctic. Vol. VII. Oxford Univ Press, Oxford.

Cramp S (ed) (1988). The Birds of the Western Palearctic. Vol. V. Oxford University Press, Oxford.

CRAMP S \& SimMONS KEL (Eds) (1977). The Birds of the Western Palearctic. Vol. I. Oxford University Press, Oxford.

CRAMP S \& SimMONS KEL (eds) (1980). The Birds of the Western Palearctic. Vol. II. Oxford University Press, Oxford.

CRAMP S \& SimMONS KEL (eds) (1983). The Birds of the Western Palearctic. Vol. III. Oxford University Press, Oxford.

Croci S, Butet A \& Clergeau P (2008) Does urbanization filter birds on the basis of their biological traits? The Condor 110: 223-240.

CZAIJKA C, BRAUN MP \& WinK M (2011). Resource use by non-native Ring-Necked Parakeets (Psittacula krameri) and native Starlings (Sturnus vulgaris) in Central Europe. The Open Ornithological Journal, 4: 17-22.

De GraAf RM, GeIs AD \& HeAly PA (1991). Bird population and habitat surveys in urban areas. Landscape and Urban Planning, 21: 181-188.

DoDARO G \& BATTISTI C (2014). Rose-ringed parakeet (Psittacula krameri) and starling (Sturnus vulgaris) syntopics in a Mediterranean urban park: evidence for competition in nest-site selection? Belgian Journal of Zoology, 144: 5-14.

Dyтнам C (2011). Choosing and using statistic. A Biologist's guide. Wiley-Blackwell, UK.
Fauth Je, Bernardo J, Camara M, Resetarits WJ, VAN BUSKIRK J \& MCCOLlIN SA (1996). Simplifying the jargon of community ecology: a conceptual approach. American Naturalist, 147: 282-286.

FEARE CJ (1984). The starling. Oxford University Press, New York.

FERNÁNDEZ-JURICIC E \& JOKIMÄKI J (2001). A habitat island approach to conserving birds in urban landscapes: case studies from southern and northern Europe. Biodiversity and Conservation, 10: 2023-2043.

FERNÁNDEZ-JURICIC E (2000). Bird community composition patterns in urban parks of Madrid: The role of age, size and isolation. Ecological Research, 15: 373-383.

Fraissinet M \& FULGIONE D (2008). Comparative analysis of the breeding avifauna of Italian cities. Avocetta, 32: 21-30.

FreEMAN SN, Robinson RA, CLARK JA, GRIFFIN BM \& ADAMS SY (2007). Changing demography and population decline in the common starling (Sturnus vulgaris): a multisite approach to integrated population monitoring. Ibis, 149: 587596.

GREGORY RD, Vorisek P, VAN STRIEN A, GMELIG Meyling AW, Jiguet F, Fornasari L, Reif J, ChylareCKI P \& BuRFIELd IJ (2007). Population trends of widespread woodland birds in Europe. Ibis, 149 (Suppl. 2): 78-97.

GUTHERY FS (2007). Deductive and inductive methods of accumulating reliable knowledge in wildlife science. Journal of Wildlife Management, 71: 222-225.

Hermansen JS, SÆTher SA, ElgVin TO, Borge T, HJELLE E \& SÆTRE G-P (2011). Hybrid speciation in sparrows I: phenotypic intermediacy, genetic admixture and barriers to gene flow. Molecular Ecology, 20: 3812-3822.

Kelcey JG \& Rheinwald G (2005). Birds in European Cities. Ginster Verlag, St. Katharinen, Germany.

KoENIG WD (2003). European Starlings and their effect on native cavity-nesting birds. Conservation Biology 17: 1134-1140.

JOKIMÄKI J, KAISANLAHTI-JOKIMÄKI M-L, SORACE A, FERnÀndeZ-Juricic E, Rodriguez-Prieto I, JIMENEZ M D (2005). Evaluation of the "safe nesting zone" hypothesis across an urban gradient: a multi-scale study. Ecography 28: 59-70. 
JOKIMÄKI J \& HUHTA E (2000). Artificial nest predation and abundance of birds along an urban gradient. Condor 102: 838-847.

JOKIMÄKI J (1999). Occurrence of breeding bird species in urban parks: Effects of park structure and broad-scale variables. Urban Ecosystems 3: 21-34.

JOKIMÄKI J \& SUHONEN J (1993). Effects of urbanization on the breeding bird species richness in Finland: a biogeographical comparison. Ornis Fennica, 70: 71-77.

MAGURRAN A(2004). Measuring biological diversity. Blackwell Publishing, Malden, MA.

MAGURRAN AE \& PHILliP SAT (2001). Implications of species loss in freshwater fish assemblages. Ecography, 24: 645-650.

MagurRan AE, BAILlie SR, BuckLAND ST, Dick J Mc P, Elston DA, SCOTT EM, SMith RI, SOMERFIELD PJ \& WATT AD (2010). Long-term datasets in biodiversity research and monitoring: assessing change in ecological communities through time. Trends in Ecology and Evolution, 25: 574-582.

MCCAFFREY RE \& MANNAN RW (2012). How scale influences birds' responses to habitat features in urban residential areas. Landscape and Urban Planning, 105: 274-280.

MCKINNEY ML (2002). Urbanization, biodiversity, and conservation. BioScience, 52: 883-890.

MikUsinsKi G, GROMADZKI M \& CHYLARECKI P (2001). Woodpeckers as indicators of forest bird diversity. Conservation Biology, 15: 208-217.

Mori E, Di Febbraro M, Foresta M, Melis P, ROMANAZZI E, NOTARI A \& BOGGIANO F (2013). Assessment of the current distribution of freeliving parrots and parakeets (Aves: Psittaciformes) in Italy: a synthesis of published data and new records. Italian Journal of Zoology, 80: 158-167.

Newson SE, Johnston A, PARrotT D \& LeECh DI (2011). Evaluating the population-level impact of an invasive species, Ring-necked Parakeet Psittacula krameri, on native avifauna. Ibis, 153: 509-516.

ORCHAN Y, CHIRON F, SHWARTZ A, KARK S (2013). The complex interaction network among multiple invasive bird species in a cavity-nesting community. Biological Invasions, 15: 429-445.

ORTEGA-ÁlVAREZ R \& MACGREGOR-Fors I (2009). Living in the big city: Effects of urban landuse on bird community structure, diversity, and composition. Landscape and Urban Planning, 90: 189-195.

PALOMINO D \& CARRASCAL LM (2006). Urban influence on birds at a regional scale: A case study with the avifauna of northern Madrid province. Landscape and Urban Planning, 77: 276-290.

PASINELLI G (2007). Nest site selection in middle and great spotted woodpeckers Dendrocopos medius and D. major: implication for forest management and conservation. Biodiversity and Conservation, 16: 1283-1298.

PENCZAK T \& KRUK A (1999). Applicability of the abundance/biomass comparison method for detecting human impact on fish populations in the Pilica River, Poland. Fisheries Research, 39: 229-240.

Prete S, Battisti C, Marini F \& Ciucci P (2012). Applying abundance/biomass comparisons on a small mammal assemblage from Barn owl (Tyto alba) pellets (Mount Soratte, central Italy): a cautionary note. Rendiconti Lincei, 23: 349-354.

PYŠEK P \& HuLME PE (2011). Biological invasions in Europe 50 years after Elton: time to sound the alarm. In: RICHARDSON DM (ed.), Fifty years of invasion ecology: the legacy of Charles Elton. Blackwell Publishing, Oxford: 73-88.

RAMALHO CE \& HoBBS RJ (2012). Time for a change: dynamic urban ecology. Trends in Ecology and Evolution, 27: 179-188.

Regione LAZIO (1990). Technical Regional Map, scale 1:10,000. Regione Lazio, Rome, Italy.

REIF J (2013). Long-term trends in bird populations: a review of patterns and potential drivers in North America and Europe. Acta Ornithologica, 48: $1-16$.

Ricotta C, Celesti Grapow L, Avena G \& Blasi C (2001). Topological analysis of the spatial distribution of plant species richness across the city of Rome (Italy) with the echelon approach. Landscape and Urban Planning, 57: 69-76.

ROMESBURG HC (1981). Wildlife science: gaining reliable knowledge. Journal of Wildlife Management, 45: 293-313.

SHANNON CE \& WEAVER W (1963). Mathematical theory of communication. University of Illinois Press. Urbana, Illinois.

SERESS G \& LIKER A (2015) Habitat urbanization and its effects on birds. Acta Zoologica Academiae Scientiarum Hungaricae, 61: 373-408. 
SORACE A \& GUSTIN M (2008). Homogenisation and local effects on avifaunal composition in Italian towns. Acta Oecologica, 33: 15-26.

SPSS INC. (2003). SPSS for Windows - Release 13.0 (1 Sep 2004), Leadtools (c), Lead Technologies Inc.

StRubBe D \& MATTHYSEN E (2007). Invasive ringnecked parakeets Psittacula krameri in Belgium: habitat selection and impact on native birds. Ecography, 30: 578-588.

STRUBBE D \& MATTHYSEN E (2009a). Establishment success of invasive ring-necked and monk parakeets in Europe. Journal of Biogeography, 36: 2264-2278.

STRUBBE D \& MATTHYSEN E (2009b). Experimental evidence for nest-site competition between invasive Ring-necked Parakeets (Psittacula krameri) and native Nuthatches (Sitta europaea). Biological Conservation, 142: 1588-1594.

SuMMER-SMITH JD (2003). The decline of the House Sparrow: a review. British Birds, 96: 439-446.
Sutherland WJ (2006.) Ecological Census Techniques. Blackwell, Massachussets.

TURČEK FJ (1956). Zur Frage der Dominanz in Vogelpopulationen. Waldhygiene 8: 249-257.

VERNER J (1984). The guild concept applied to management of bird populations. Environmental Management, 8: 1-14.

WARWICK RM (1986). A new method for detecting pollution effects on marine macrobenthic communities. Marine Biology, 92: 557-562.

ZANGARi L, FERRAGUTI M, LUISELli L, BATTISTI C \& BolognA MA (2013). Comparing patterns in abundance and diversity of hole-nesting birds in Mediterranean habitats. Revue d'Écologie (Terre Vie), 68: 275-282.

Received: 24 November 2015

Accepted: 15 April 2016

Branch editor: Diederik Strubbe 